\title{
Skin lesion-associated pathogens from Octopus vulgaris: first detection of Photobacterium swingsii, Lactococcus garvieae and betanodavirus
}

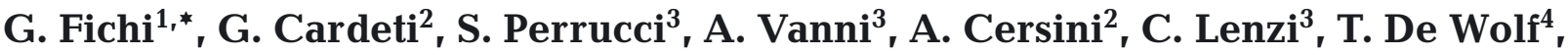 \\ B. Fronte ${ }^{3}$, M. Guarducci ${ }^{1}$, F. Susini ${ }^{1}$ \\ ${ }^{1}$ Istituto Zooprofilattico Sperimentale delle Regioni Lazio e Toscana, S.S. dell'Abetone e del Brennero 4, 56123 Pisa, Italy \\ ${ }^{2}$ Istituto Zooprofilattico Sperimentale delle Regioni Lazio e Toscana, Via Appia Nuova 1411, 00178 Roma, Italy \\ ${ }^{3}$ Dipartimento di Scienze Veterinarie - University of Pisa, Viale delle Piagge 2, 56124 Pisa, Italy \\ ${ }^{4}$ Maricoltura di Rosignano Solvay, Via P. Gigli snc, 57016 Rosignano Solvay, Italy
}

\begin{abstract}
The common octopus Octopus vulgaris Cuvier, 1798 is extremely important in fisheries and is a useful protein source in most Mediterranean countries. Here we investigated pathogens associated with skin lesions in 9 naturally deceased specimens that included both cultured and wild common octopus. Within $30 \mathrm{~min}$ after death, each octopus was stored at $4{ }^{\circ} \mathrm{C}$ and microbiologically examined within $24 \mathrm{~h}$. Bacterial colonies, cultured from swabs taken from the lesions, were examined using taxonomical and biochemical analyses. Vibrio alginolyticus and V. parahaemolyticus were only isolated from cultured animals. A conventional PCR targeting the $16 \mathrm{~S}$ ribosomal RNA (rRNA) gene and sequencing were performed on 2 bacterial isolates that remained unidentified after taxonomical and biochemical analysis. The sequence results indicated that the bacteria had a $99 \%$ identity with Lactococcus garvieae and Photobacterium swingsii. L. garvieae was confirmed using a specific PCR based on the 16S-23S rRNA internal transcribed spacer region, while $P$. swingsii was confirmed by phylogenetic analyses. Although all animals examined were found to be infected by the protozoan species Aggregata octopiana localised in the intestines, it was also present in skin lesions of 2 of the animals. Betanodavirus was detected in both cultured and wild individuals by cell culture, PCR and electron microscopy. These findings are the first report of $L$. garvieae and betanodavirus from skin lesions of common octopus and the first identification of $P$. swingsii both in octopus skin lesions and in marine invertebrates in Italy.
\end{abstract}

KEY WORDS: Common octopus $\cdot$ Vibrionaceae $\cdot$ Streptococcaceae $\cdot$ Nodaviridae $\cdot$ Aggregata octopiana

\section{INTRODUCTION}

The common octopus Octopus vulgaris Cuvier, 1798 is a cephalopod mollusc that is extremely important in fisheries and represents an important protein source in most Mediterranean countries (Estévez et al. 1996). Since the decline of traditional fisheries, $O$. vulgaris has been considered a candidate species in European aquaculture because of its easy acclimatization to farming conditions, rapid growth and high market value (Castellanos-Martínez \& Gestal 2013). Octopus on-growing is currently being developed on an industrial scale in Galicia (Spain) (CastellanosMartínez \& Gestal 2013), while experimental studies in Italy have examined reproduction and larvae ongrowing (De Wolf et al. 2011). One of the disadvantages of octopus aquaculture is the increase in the incidence of diseases caused by bacteria, viruses and parasites that could be a serious risk to production (Castellanos-Martínez \& Gestal 2013). Despite the 
importance of $O$. vulgaris, little information is available on diseases occurring in wild populations of this species (Farto et al. 2003). Viruses, bacteria and parasites have been found associated with skin lesions in cephalopods (Scimeca 2012).

Bacteria in skin lesions of different Octopus species, including $O$. vulgaris, $O$. joubini and $O$. briareus, have been reported mainly from cultured subjects, but also from wild individuals (Romalde \& Barja 2010). The main signs observed in diseased octopus are skin ulcers, which can result in deep wounds in the head, mantle or arms (Scimeca 2012). Aeromonas cavieae, A. hydrophila, Pseudomonas stutzeri and various Vibrio species (i.e. $V$. alginolyticus, $V$. anguillarum, $V$. harveyi and $V$. parahaemolyticus), have been associated with these lesions (Romalde \& Barja 2010). In addition, Farto et al. (2003) isolated $V$. lentus from gills, branchial-heart and skin lesions of wild common octopus in Spain, confirming its pathogenic potential.

Aggregata spp. (Protozoa: Apicomplexa) coccidian parasites are considered the dominant epizootiological agents in wild and cultured octopus stocks in Europe (Gestal et al. 2002a, 2007). In severe forms, Aggregata spp. infection spreads from the digestive tract to the mantle and the gills, affecting the connective tissue and epithelium of these organs and causing the appearance of white cysts associated with host cell hypertrophy with nuclear displacement, inflammation, phagocytosis, ulceration, and destruction of the organ architecture (Gestal et al. 2002b, CastellanosMartínez \& Gestal 2013). A. octopiana is the only species of this genus reported in common octopus (Estévez et al. 1996, Castellanos-Martínez et al. 2013).

Viruses infect most marine organisms, from bacteria to invertebrates and vertebrates (Pierce et al. 2010). Cephalopods, including common octopus, have been found to contain virus-like particles, probably of the genus Iridovirus, associated with tumours in the muscle tissue of the arms and, in advanced stages, on the funnel and the ventral surface of the mantle (Farley 1978, Hanlon \& Forsythe 1990).

The aim of the present study was to investigate the pathogens associated with skin lesions in cultured and wild common octopus.

\section{MATERIALS AND METHODS}

\author{
Animals \\ Between May 2011 and December 2012, a total of 9 \\ naturally deceased specimens of wild and cultured \\ adult and sub-adult common octopus exhibiting skin
}

lesions were examined. Within $30 \mathrm{~min}$ after death, each octopus was stored at $4{ }^{\circ} \mathrm{C}$ and microbiologically examined within $24 \mathrm{~h}$.

Six sample animals were cultured specimens (3 females and 3 males) obtained from the research centre for marine species 'Maricoltura di Rosignano Solvay' (MRS) in Livorno, Italy; these included 4 adults ( 2 males and 2 females), which were in the final stage of their reproductive cycle, and 2 sub-adults ( 1 male and 1 female) at the beginning of the production season. The remaining 3 specimens were commercial-caught wild specimens and included 2 adult males caught in Viareggio (Lucca, Italy) and 1 adult male caught in Livorno, Italy.

\section{Post-mortem examination}

Each octopus was examined for external clinical abnormalities and post-mortem lesions. Samples for parasitological investigation were taken and immediately analysed as fresh samples or fixed in $10 \%$ buffered formalin for histological examination. Inocula for bacteriological investigation were taken and promptly examined, while samples for virological investigation were stored at $-80^{\circ} \mathrm{C}$ prior to examination.

\section{Parasitological investigation}

Fresh smears and scrapes of skin, gill, intestine, kidney and the mesenterium covering of the intestine and other internal organs were examined microscopically for the presence of parasites. In addition, in order to investigate the presence of Aggregata spp. in histological lesions, skin samples were fixed in $10 \%$ buffered formalin, dehydrated in a graded ethanol series, embedded in paraplast (JB-4 Polysciences) and sectioned using a microtome. Sections $(3 \mu \mathrm{m})$ were stained with haematoxylin-eosin (Carlo Erba Reagents) following standard procedures and observed under a light microscope.

\section{Bacteriological investigation}

Inocula from skin mantle lesions, brain and branchial-heart were taken with a flame-sterilized loop and plated onto $2 \% \mathrm{NaCl}$ tryptone soya agar and blood agar plates. The cultures were incubated at $25^{\circ} \mathrm{C}$ for $36 \mathrm{~h}$. Developing colonies were examined 
using taxonomical analyses according to Holt et al. (1994), and biochemical reactions were performed using API test strips (Biomerieux ${ }^{\mathrm{TM}}$ ).

Strains that were not identified by taxonomical and biochemical reactions were identified using 16S ribosomal RNA (rRNA) PCR assay. Bacterial DNA was extracted using a QiaAmp Blood and Tissue kit (Qiagen). A conventional PCR targeting the 16S rRNA gene with the universal bacteria primers $27 \mathrm{~F}$ and $1525 \mathrm{R}$ (5'-GAG TTT GAT CCT GGC TCA G-3' and 5'-AAG GAG GTG WTC CAR CC-3', respectively) was run as previously described (Blackall et al. 2001). The resulting PCR products were purified using a PCR purification kit (EuroGOLD Gel Extraction Kit, Euroclone) and sequenced. These were compared with previously published sequences deposited in GenBank using BLAST. The absence of chimeric 16S rRNA sequences was confirmed by the use of the ss_DECIPHER algorithm (Wright et al. 2012). Sequenced products of 16S RNA gene PCR were aligned with sequences of strains deposited in GenBank, and the phylogenetic trees of 16S RNA genes were constructed using neighbour joining, maximum parsimony and maximum likelihood algorithms of Seaview software (Gouy et al. 2010).

In order to confirm strain identity as Lactococcus garvieae by GenBank comparison, a specific PCR based on the 16S-23S rRNA internal transcribed spacer region of $L$. garvieae was performed using primers ITSLg30F (5'-ACT TTA TTA TTC AGT TTT GAG GGG TCT-3') and ITSLg319R (5'-TTT AAA AGA ATT CGC AGC TTT ACA-3') as previously described by Dang et al. (2012). A L. garvieae isolate, obtained from the Italian Reference Centre for the Study and Diagnosis of Diseases of Fish, Molluscs and Crustaceans (Istituto Zooprofilattico Sperimentale delle Venezie) was used as a positive control, while molecular grade water (5 Prime) was used as a negative control.

\section{Virological investigation}

Skin lesions, eyes, branchial-heart and brain of adult and sub-adult octopuses were homogenised by mortar with sterile sand, and each sample was suspended 1:10 in Eagle's minimum essential medium (EMEM), supplemented with $10 \% \mathrm{v} / \mathrm{v}$ foetal calf serum $(\mathrm{FCS})$ and $2 \% \mathrm{v} / \mathrm{v}$ of antibiotic-antimycotic solution (penicillin $100 \mathrm{UI} \mathrm{ml}^{-1}$, streptomycin sulphate $10 \mathrm{mg} \mathrm{ml}^{-1}$ and amphotericin B $25 \mathrm{\mu g} \mathrm{ml}^{-1}$; Sigma Aldrich).
Tissue homogenates were centrifuged at $3000 \times g$ (30 min), filtered through $0.45 \mu \mathrm{m}$ membranes and incubated overnight at $4^{\circ} \mathrm{C}$. Bluegill fry (BF-2), epithelioma papulosum cyprini (EPC) and striped snakehead (SSN-1) cell lines were routinely grown in $25 \mathrm{~cm}^{2}$ tissue culture flasks (BD Falcon ${ }^{\mathrm{TM}}$ ) in cell culture EMEM supplemented with $10 \%$ FCS, $1 \%$ L-glutamine and $1 \%$ antibiotic-antimycotic solution (Sigma Aldrich) at $25^{\circ} \mathrm{C}$. Sample extracts were inoculated at 2 ten-fold dilutions (1:10 and 1:100) onto $1 \mathrm{~d}$ old BF-2, EPC and SSN-1 monolayers grown in 24-well cell culture plates (BD Falcon ${ }^{\mathrm{TM}}$ ). BF-2 and ECP cell culture plates were incubated at $15^{\circ} \mathrm{C}$ for the isolation of birnavirus and reovirus, and at $22^{\circ} \mathrm{C}$ for iridovirus isolation. Organ tissue extracts were inoculated at the same conditions onto SSN-1 cell culture and incubated at $22^{\circ} \mathrm{C}$ for the betanodavirus isolation.

After inoculation, plates were observed daily for detection of a cytopathic effect (CPE). After $7 \mathrm{~d}$, supernatants were used to inoculate actively growing SSN-1, EPC and BF-2 cells, and 2 more $7 \mathrm{~d}$ long passages were done before considering the samples negative.

Eyes, branchial-heart, brain and skin lesions of adult and sub-adult octopuses were collected and analysed by negative staining transmission electron microscopy (nsTEM). The samples were homogenised, centrifuged for $30 \mathrm{~min}$ at $3000 \times g$ and then at $9000 \times g$, and ultra-centrifuged at $90000 \times g$ for $20 \mathrm{~min}$. Finally, the samples were negative stained with $2 \%$ sodium phosphotungstate $(\mathrm{pH}$ 6.8) and observed by TEM (Philips EM 208) at 28 000-36 000x magnification (Biel \& Gelderblom 1999).

The real-time PCR (RT-PCR) for the detection of betanodavirus amplifies a conserved $69 \mathrm{bp}$ region of the viral genome localised in the RNA2 strand, coding for the coat protein (CP) (Panzarin et al. 2010).

Total RNA was extracted from a $140 \mu l$ sample using the Viral RNA Mini Kit (QIAamp ${ }^{\circledR}$, Qiagen) following the supplier's recommendations. The cDNA was synthesized using random hexamers with the High Capacity cDNA Reverse Transcription kit (Applied Biosystems) according to the manufacturer's instructions. Real-time PCR was performed using the 7900HT Fast Real Time System (Applied Biosystems) and carried out in $25 \mu \mathrm{l}$ with TaqMan ${ }^{\circledR}$ Universal PCR Master Mix kit (Applied Biosystems), $0.75 \mu \mathrm{l}$ of each primer, $0.75 \mu \mathrm{l}$ of probe and $5 \mu \mathrm{l}$ of cDNA template. The thermal profile consisted of a cycle at $50^{\circ} \mathrm{C}$ for $2 \mathrm{~min}$, a $10 \mathrm{~min}$ incubation at $95^{\circ} \mathrm{C}$ followed by 50 cycles of $15 \mathrm{~s}$ denaturation at $95^{\circ} \mathrm{C}$, $30 \mathrm{~s}$ annealing at $52^{\circ} \mathrm{C}$ and 1 min elongation at $60^{\circ} \mathrm{C}$. 


\section{RESULTS}

The prevalent lesions observed in this study (Table 1) were white skin lesions on the head (Fig. 1a) and arms of both cultured and wild specimens, including 4 cultured octopuses and 2 octopuses caught in Viareggio. A skin lesion with an oval outline and retracted margins was found on the head of an adult male caught in Livorno (Fig. 1b). Areas of discolouration and lesions related to trauma in the arms (Fig. 1c) of 4 cultured octopuses and absence of arms in a further cultured subject and an octopus caught in Viareggio were also observed. A retrobulbar lesion with a yellowish fluid material was found in an adult cultured male (Fig. 1d). Three animals ( 2 cultured adult females and 1 adult male caught in Viareggio) appeared in poor condition with a reduced size of digestive glands compared to what is normally observed in healthy individuals.

Aggregata octopiana lesions were found in skin and muscular tissues of 2 cultured females at the end of the reproductive season. In particular, histological examination showed A. octopiana oocysts in the internal wall of the mantle (Fig. 2a) surrounded by intense infiltrations of haemocytes (Fig. 2b), while in the skin, only free sporocysts, located superficially in the thick reticular fibres of collagen, were found (Fig. 2c,d). Finally, parasitological examination showed intestinal Aggregata cystic lesions in the caecum of all animals.

Vibrio alginolyticus was identified from skin and branchial-heart lesion samples of 2 females deceased at the end of the reproductive season, collected and maintained as previously described, and microbiologically examined respectively 12 and $15 \mathrm{~h}$ after death. V. parahaemolyticus was isolated from skin lesions of the female examined $12 \mathrm{~h}$ after death. Another Vibrionaceae, isolated from skin and retrobulbar lesion samples of a male collected and maintained as previously described and microbiologically examined $5 \mathrm{~h}$ after death, remained unidentified at the species level by taxonomical and biochemical reactions. The physical and biochemical characteristics of this species are reported in Table 2. The sequenced 16S rRNA gene PCR product (1484 bp, strain MB86-15, GenBank accession number KJ959592) presented 99.04\%

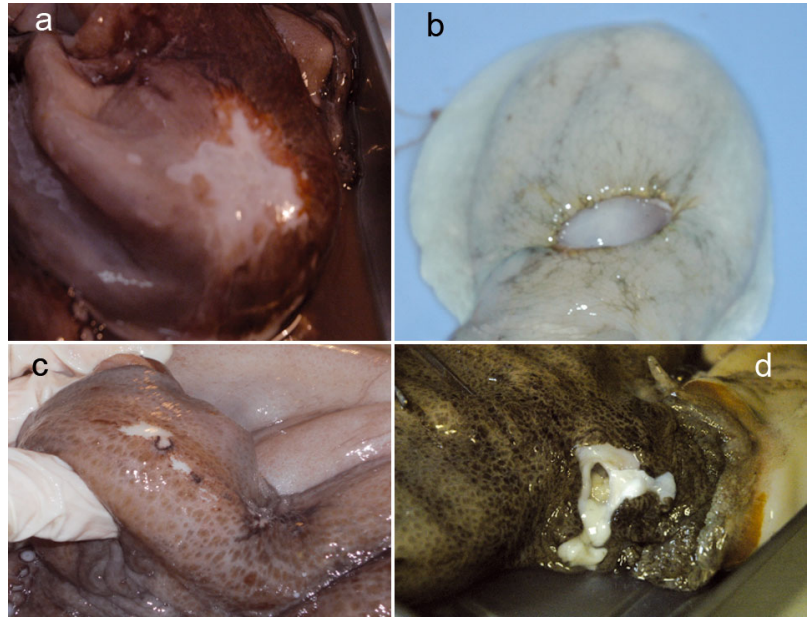

Fig. 1. Skin lesions observed in wild and cultured examined common octopus Octopus vulgaris: (a) white skin lesion on head; (b) skin lesion with oval outline and retracted margins; (c) area of discolouration on an arm; (d) retrobulbar lesion with yellowish fluid material

identity with Photobacterium swingsii 16S rRNA gene isolate AP067 (GenBank accession number HE584802.1) and Vibrio sp. V125 16S ribosomal RNA gene, partial sequence (GenBank accession number DQ146977.1). Phylogenetic analysis with a reference genomic sequence of Photobacterium spp. and with P. swingsii strains isolated by Gomez-Gil et al. (2011)
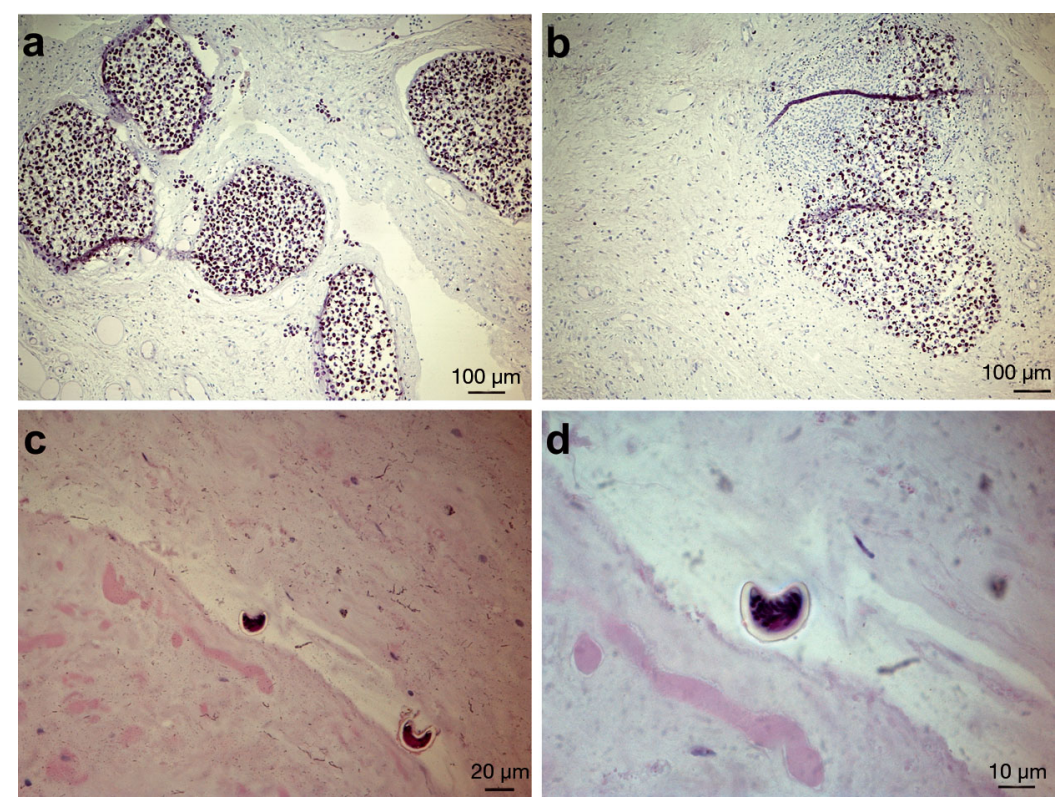

Fig. 2. Histological examination for Aggregata octopiana infecting common octopus Octopus vulgaris: (a) oocysts in internal wall of the mantle; (b) tissue response characterised by intense infiltration of hemocytes in internal wall of the mantle; (c) free sporocysts in the thick reticular fibres of skin collagen; (d) free sporocyst in skin 


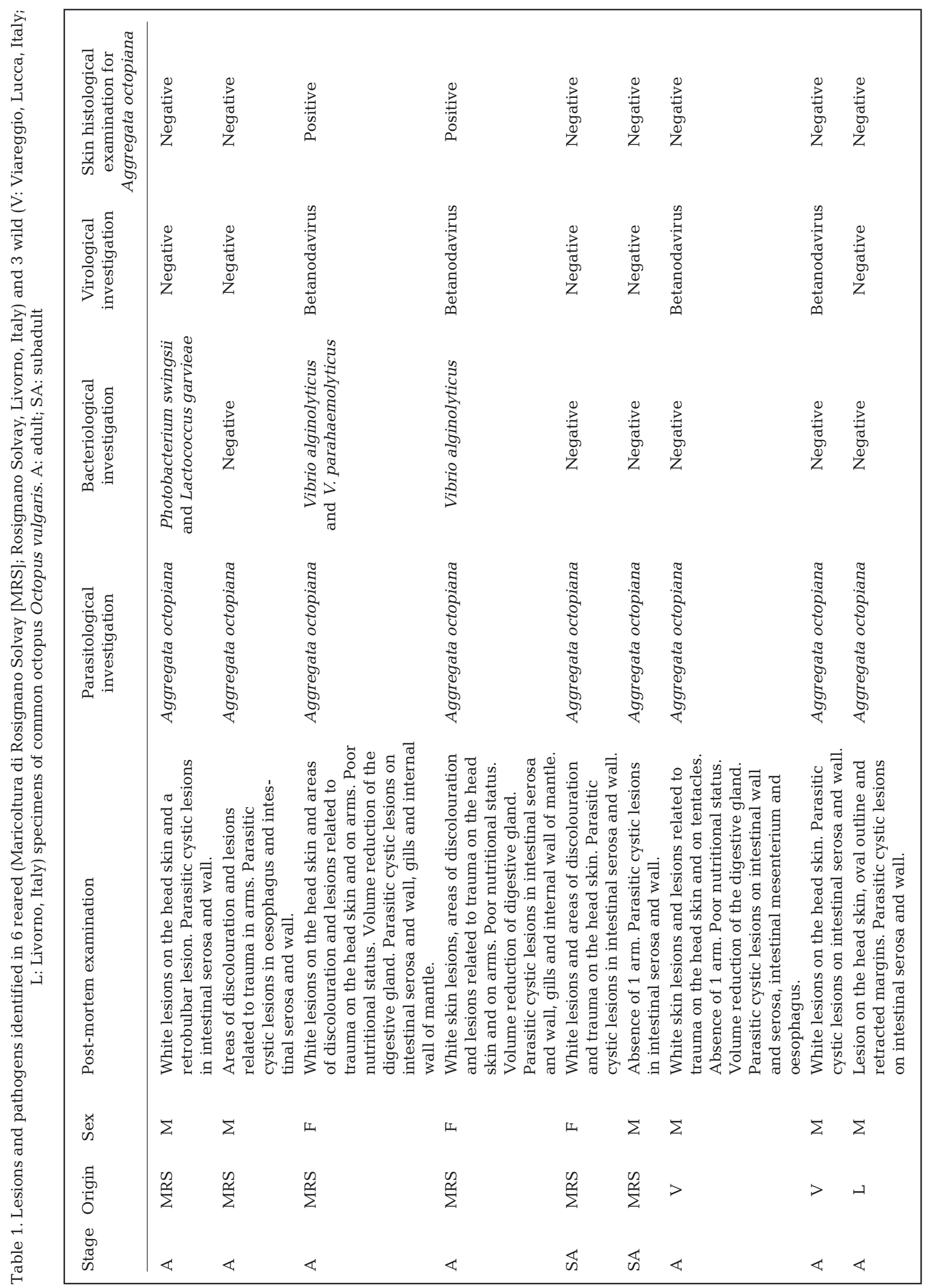


a)

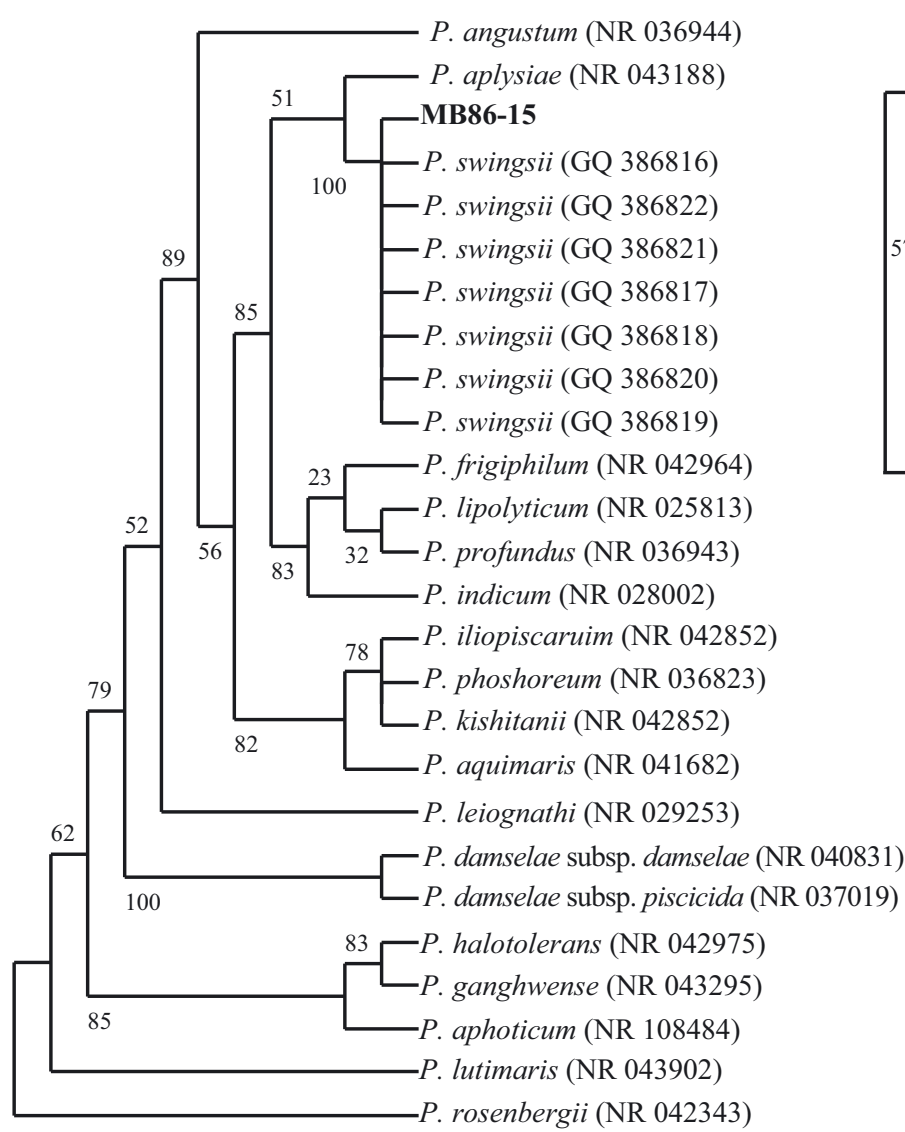

c)

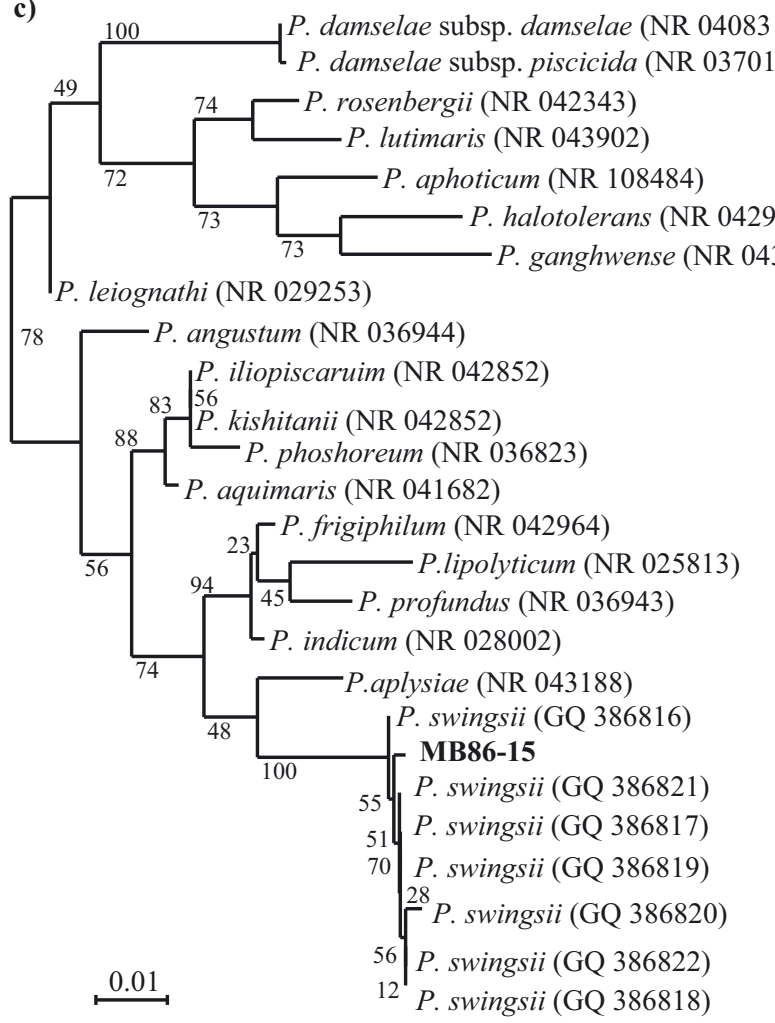

b)

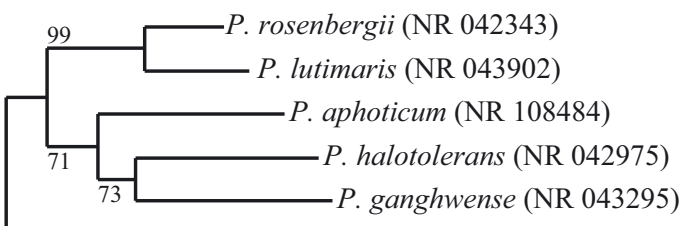

P. damselae subsp. damselae (NR 040831)
P. damselae subsp. piscicida (NR 037019)
Fig. 3. (a) Maximum parsimony, (b) neighbour-joining and (c) maximum likelihood dendrograms, based on almost-complete (1310 bp) 16S rRNA gene sequences, showing the position of strains of MB86-15 among their closest phylogenetic neighbours. Bootstrap values based on 1000 replicates are shown at branch nodes 
Table 2. Physical and biochemical features of the Photobacterium swingsii strain isolated from common octopus Octopus vulgaris. TSA: tryptone soya agar; TCBS: thiosulphate citrate bile salts sucrose agar; SIM: sulphur reduction/indole production/motility medium; OF: oxidation fermentation; KIA: Kligler iron agar; O129: vibriostatic agent (S: susceptible)

\begin{tabular}{|c|c|}
\hline Characteristic & Reaction \\
\hline Gram stain & - \\
\hline Motility & + \\
\hline Cytochrome oxidase & + \\
\hline Catalase & + \\
\hline \multicolumn{2}{|l|}{ Growth on: } \\
\hline TSA & + \\
\hline MacConkey agar & - \\
\hline Blood agar & + \\
\hline TCBS & Green \\
\hline SIM & Motile \\
\hline & No sulphur reduction \\
\hline OF & Fermentative \\
\hline KIA & $\begin{array}{c}\text { Glucose fermentative } \\
\text { Lactose not fermentative }\end{array}$ \\
\hline O129 $10 \mu \mathrm{g}$ & $\mathrm{S}$ \\
\hline O129 $150 \mu \mathrm{g}$ & $\mathrm{S}$ \\
\hline \multicolumn{2}{|l|}{ Growth in: } \\
\hline $0 \% \mathrm{NaCl}$ & - \\
\hline $3 \% \mathrm{NaCl}$ & + \\
\hline $8 \% \mathrm{NaCl}$ & - \\
\hline \multicolumn{2}{|l|}{ Acid production from: } \\
\hline Glucose & + \\
\hline Lactose & - \\
\hline \multicolumn{2}{|l|}{ Growth at: } \\
\hline $4^{\circ} \mathrm{C}$ & - \\
\hline $22^{\circ} \mathrm{C}$ & + \\
\hline $30^{\circ} \mathrm{C}$ & + \\
\hline $37^{\circ} \mathrm{C}$ & + \\
\hline
\end{tabular}

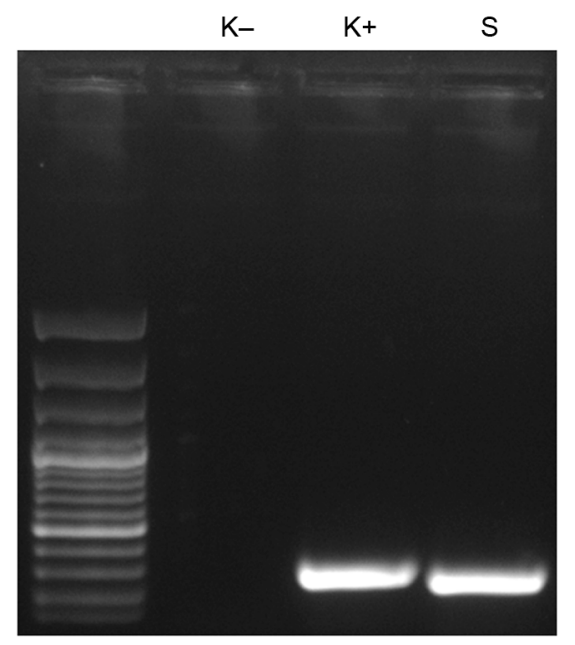

$290 \mathrm{bp}$

Fig. 4. Specific PCR products of the 16S-23S rRNA internal transcribed spacer region of Lactococcus garvieae (K-: negative control, bio-molecular grade water; $\mathrm{K}+$ : positive control L. garvieae; S: sample) and $100 \mathrm{bp}$ DNA ladder (Thermo Scientific) confirmed the identification of the MB86-15 strain as P. swingsii (Fig. 3).

Gram-positive lactobacilli were detected from the same lesions of this male subject. The sequenced $16 \mathrm{~S}$ rRNA gene PCR product presented $99.00 \%$ identity with Lactococcus garvieae. Specific PCR on the 16S23S rRNA internal transcribed spacer region of L. garvieae confirmed the identification of this species (Fig. 4).

Betanodavirus species were isolated by cell cultures from samples of skin lesions and eyes of 2 cultured females deceased at the end of the reproductive season, collected and maintained as previously described, microbiologically examined respectively 12 and $15 \mathrm{~h}$ after death, and stored at $-80^{\circ} \mathrm{C}$; and from skin lesions and branchial-heart samples of 2 males caught in Viareggio, collected and maintained as previously described, examined respectively 4 and $6 \mathrm{~h}$ after death, and stored at $-80^{\circ} \mathrm{C}$. PCR confirmed the presence of betanodavirus RNA in all of these samples, while electron microscopic examination showed the presence of nodavirus-like elements (without envelope, spherical in shape and $25 \mathrm{~nm}$ diameter) only in skin lesions from a single subject, i.e. a reared adult female (Fig. 5). Table 1 shows lesions and associated pathogens found in each examined common octopus.

\section{DISCUSSION}

Few reports have described diseases in octopus, and almost all are related to cultured animals, which are subjected to more favourable conditions for the spread of diseases (Farto et al. 2003). In the present study, we report the first bacterial, parasitological and virological investigation of skin lesions in wild and cultured octopuses. Skin gross lesions described in common octopus are mainly represented by white skin lesions and ulcerative lesions (Anderson et al. 2002, Farto et al. 2003). Cephalopods carry a diverse assemblage of pathogens and symbionts, and apparently 'healthy' individuals in the wild appear able to survive trauma without suffering major infections (Pierce et al. 2010). Both young and senescent octopuses can show white skin lesions (Anderson et al. 2002). However, young octopuses living in good condition and in good water quality can overcome the negative effects of an injury that may cause such lesions. In older animals, skin injuries may often become secondarily infected with Aeromonas, Vibrio and Staphylococcus bacteria (Anderson et al. 2002). Accordingly, in the present study bacteria were isolated only from skin lesions of older animals, namely 


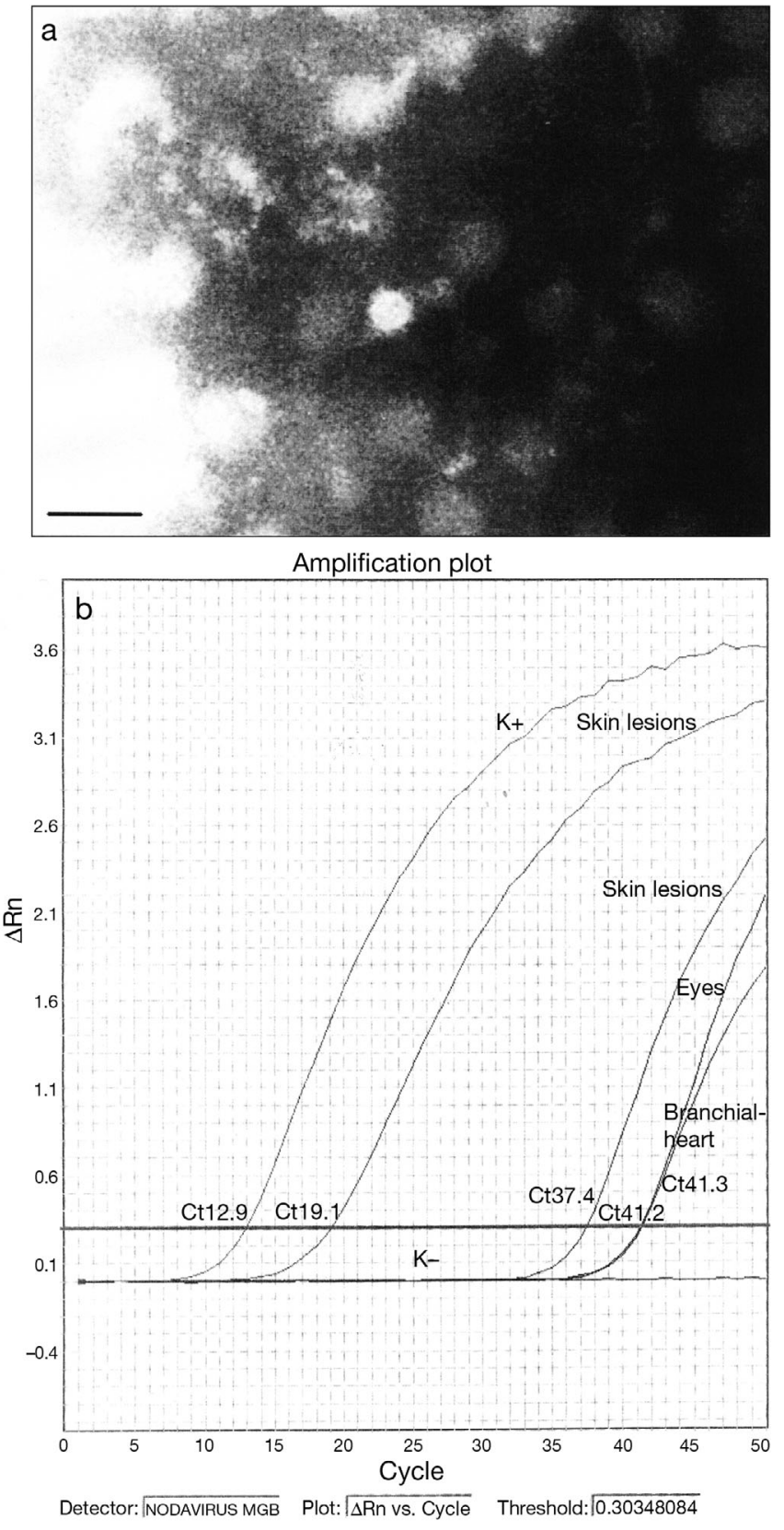

Fig. 5. (a) Nodavirus-like elements observed in the skin of common octopus Octopus vulgaris (cultured adult female) by transmission electron microscopy examination (scale bar $=50 \mathrm{~nm}$ ). (b) Betanodavirus real-time PCR results; horizontal line shows detection threshold (K-: negative control, biomolecular grade water; $\mathrm{K}+$ : positive control beta-nodavirus; Ct: threshold cycle)

a cultured male and 2 females at the end of the reproductive season.

As reported by Farto et al. (2003), Vibrionaceae were the most frequently found bacteria associated with skin lesions, and the species identified here, i.e. $V$. alginolyticus and $V$. parahaemolyticus, have been previously isolated in common octopus skin lesions (Hanlon et al. 1984, Hanlon \& Forsythe 1990, Farto et al. 2003). The phenotypic description of strain MB8615 reported here is in accord with $P$. swingsii. Sequencing and phylogenetic analysis of strain MB8615 confirm its identity as $P$. swingsii.

$P$. swingsii was recently isolated and characterised by repetitive palindromic PCR (rep-PCR) and phylogenetic analysis in cultured oysters in Mexico and from haemolymph of wild spider crabs in Spain (Gomez-Gil et al. 2011). Strain MB86-15 presented the highest identity (99.04) with $P$. swingsii 16S rRNA gene isolate AP067 (GenBank accession number HE584802.1) isolated from farmed Haliotis diversicolor Reeve, 1846, a strain previously identified as Vibrio sp. in aquatic animals (GenBank accession number DQ146977.1). Phylogenetic analysis showed a bootstrap value of $100 \%$ with the strains isolated from Gomez-Gil et al. (2011) (Fig. 3), confirming the strain isolated here as $P$. swingsii. This is the first isolation of $P$. swingsii in common octopus and the first isolation of this species in Italy. The isolation of this bacterial strain from an octopus lesion and previously from oysters with vibriosis could suggest a pathogenic role of this strain in these marine animals, but there is no evidence relating to the pathogenicity of $P$. swingsii in the literature. Further studies are needed to confirm this.

Among the Streptococcaceae, Lactococcus garvieae is a well-known agent responsible for hyperacute and haemorrhagic septicaemia in fish. In aquatic invertebrate animals, such as the giant freshwater prawn, it has been identified in an epizootic bacterial infection where gross pathological changes included whitish muscle with yellowish-white spots and a swollen, yellowish hepatopancreas (Chen et al. 2001, Vendrell et al. 2006). In cephalopods, this species has been reported only in the muscle of a wildcaught squid (Tsai et al. 2012). In the present study, the identification of this bacterium was confirmed by sequencing and by specific PCR on the 16S-23S rRNA internal transcribed spacer region of $L$. garvieae. This finding is the first identification of L. garvieae from common octopus skin lesions.

Although the presence of a pathogen in skin lesions does not necessarily mean it has caused a given disease, $V$. alginolyticus and $V$. parahaemolyticus have been found associated with the appearance of skin lesions in cultured octopus (Romalde \& Barja 2010). In the present study, $V$. alginolyticus infection was confirmed by isolation of the bacterium in the same animal not only from skin lesions, but also from internal organs, i.e. branchial-heart. 
One record of bacterial infections in wild octopuses was reported by Farto et al. (2003) in Spain. Lesions on the mantle were attributed to the bacteria Cytophaga-like and Pseudomonas, which were isolated from the damaged tissues, and $V$. lentus, which was isolated for the first time from the branchial-heart of octopus (Castellanos-Martínez \& Gestal 2013). In that case, experimental infections demonstrated that $V$. lentus was able to reproduce the skin lesions, colonize the internal organs and induce mortality in healthy octopus (Farto et al. 2003). It was not possible, however, to confirm the bacteria reported in the present study as the cause of death of the animals examined.

Although cephalopods are susceptible to a number of parasites (Gestal et al. 1999), Aggregata octopiana is considered the main epizootiological agent in wild and cultured octopus stocks (Gestal et al. 2007). This parasite is described in many areas of the Atlantic Ocean and the Mediterranean Sea, including the Tyrrhenian and Adriatic Seas (Licciardo et al. 2005, Mladineo \& Bocina 2007). In severe forms, the infection usually spreads from the intestinal tract to the mantle, gill connective and epithelial tissues (Mladineo \& Jozi 2005, Mladineo \& Bocina 2007, CastellanosMartínez \& Gestal 2013). A. octopiana infections are usually not fatal, but severely weaken cephalopod hosts, making them more vulnerable to other biotic and abiotic stressors (Castellanos-Martínez \& Gestal 2013). Indeed, in the present study, A. octopiana was identified in the intestine and intestinal serosa of all animals examined here, while histological examination showed parasitic cystic lesions in skin and muscular tissues of 2 cultured females also positive for $V$. alginolyticus, $V$. parahaemolyticus and betanodavirus.

The genera Alphanodavirus and Betanodavirus are members of the family Nodaviridae which includes enveloped and single-stranded RNA viruses (Shetty et al. 2012). Alphanodaviruses are insect viruses, while betanodaviruses infect both cold and warm water fish throughout the world (Shetty et al. 2012). Another group of nodaviruses, which are neither classified as alpha- nor betanodaviruses, have been reported from shrimps (NaveenKumar et al. 2013). In fish, betanodavirus infection is known as viral nervous necrosis, fish encephalitis, viral encephalopathy and retinopathy (Shetty et al. 2012). Betanodavirus infections have also been reported in marine invertebrates (Gomez et al. 2008a,b, 2010, Panzarin et al. 2012), including molluscs, such as the Mediterranean mussel Mytilus galloprovincialis Lamarck, 1819, the Japanese carpet shell Ruditapes philippinarum
(Adams \& Reeve, 1850) and the Japanese common squid Todarodes pacificus (Steenstrup, 1880). Mediterranean mussels were found to be sub-clinically infected with betanodavirus, located in the hepatopancreas (Gomez et al. 2008a), while in Japanese common squid, betanodaviruses were detected in the brain and in eyes (Gomez et al. 2008a, 2010). Based on phylogenetic analysis of the T4 variable region within the RNA2 segment, betanodaviruses have been historically divided into 4 genotypes: striped jack nervous necrosis virus (SJNNV), tiger puffer nervous necrosis virus (TPNNV), barfin flounder nervous necrosis virus (BFNNV) and red-spotted grouper nervous necrosis virus (RGNNV) (Panzarin et al. 2012). The phylogeny-based analyses of betanodaviruses previously reported in molluscs evidenced high homology with RGNNV (Gomez et al. 2008a, 2010) or RGNNV/SJNNV reassortant strains (Panzarin et al. 2012) circulating in fish in the areas of the studies. In our study, betanodaviruses were detected in skin, eyes and branchial-heart of both reared and wild common octopuses. This is the first record of betanodaviruses in this marine invertebrate. Further phylogeny-based analyses should be conducted to investigate the relationship of these betanodaviruses with fish and marine invertebrate strains detected in the same area.

In conclusion, we aimed to identify bacteria, viruses and parasites associated with skin lesions in octopus. The first isolation of $L$. garvieae and the first detection of betanodaviruses in octopuses are reported here, and indicate the possibility that this animal acts as a vector of such fish diseases. Furthermore, the first identification of $P$. swingsii in Italian wild and cultured octopus is also reported. However, further studies are needed to investigate the pathogenic role of L. garvieae, P. swingsii and betanodaviruses in the common octopus.

\section{LITERATURE CITED}

Anderson RC, Wood JB, Byrne RA (2002) Octopus senescence: the beginning of the end. J Appl Anim Welf Sci 5: 275-283

Biel SS, Gelderblom HR (1999) Electron microscopy of viruses. In: Cann AJ (ed) Virus culture-a practical approach. Oxford University Press, Oxford, p 111-147

Blackall PJ, Angen $\varnothing$, Fegan N, Blackall L, Mutters R, Bisgaard M (2001) Characterisation of a novel Mannheimia sp. from Australian feedlot cattle. Aust Vet J 79:634-639

> Castellanos-Martínez S, Gestal C (2013) Pathogens and immune response of cephalopods. J Exp Mar Biol Ecol 447:14-22

Castellanos-Martínez S, Pérez-Losada M, Gestal C (2013) Molecular phylogenetic analysis of the coccidian cephalopod parasites Aggregata octopiana and Aggre- 
gata eberthi (Apicomplexa: Aggregatidae) from the NE Atlantic coast using 18S rRNA sequences. Eur J Protistol 49:373-380

Chen SC, Lin YD, Liaw LL, Wang PC (2001) Lactococcus garvieae infection in the giant freshwater prawn Macrobranchium rosenbergii confirmed by polymerase chain reaction and 16S rDNA sequencing. Dis Aquat Org 45: 45-52

Dang HT, Park HK, Myung S, Kim W (2012) Development of a novel PCR assay based on the 16S-23S rRNA internal transcribed spacer region for the detection of Lactococcus garvieae. J Fish Dis 35:481-487

> De Wolf T, Lenzi S, Lenzi F (2011) Paralarval rearing of Octopus vulgaris (Cuvier) in Tuscany, Italy. Aquacult Res 42:1406-1414

Estévez J, Pascual S, Gestal C, Soto M, Rodríguez H, Arias C (1996) Aggregata octopiana (Apicomplexa: Aggregatidae) from Octopus vulgaris off NW Spain. Dis Aquat Org 27:227-231

Farley CA (1978) Viruses and viruslike lesions in marine mollusks. Mar Fish Rev 40:18-20

> Farto R, Armada SP, Montes M, Guisande JA, Pérez MJ, Nieto TP (2003) Vibrio lentus associated with diseased wild octopus (Octopus vulgaris). J Invertebr Pathol 83: 149-156

Gestal C, Belcari P, Abollo E, Pascual S (1999) Parasites of cephalopods in the Northern Tyrrhenian Sea (western Mediterranean): new host records and host specificity. Sci Mar 63:39-43

Gestal C, Páez de la Cadena M, Pascual S (2002a) Malabsorption syndrome observed in the common octopus Octopus vulgaris infected with Aggregata octopiana (Protista: Apicomplexa). Dis Aquat Org 51:61-65

Gestal C, Abollo E, Pascual S (2002b) Observations on associated histopathology with Aggregata octopiana infection (Protista: Apicomplexa) in Octopus vulgaris. Dis Aquat Org 50:45-49

Gestal C, Guerra A, Pascual S (2007) Aggregata octopiana (Protista: Apicomplexa): a dangerous pathogen during commercial Octopus vulgaris ongrowing. ICES J Mar Sci 64:1743-1748

Gomez DK, Baeck GW, Kim JH, Choresca CH, Park JSC (2008a) Molecular detection of betanodaviruses from apparently healthy wild marine invertebrates. J Invertebr Pathol 97:197-202

> Gomez DK, Baeck GW, Kim JH, Choresca CH, Park JSC (2008b) Genetic analysis of betanodaviruses in subclinically infected aquarium fish and invertebrates. Curr Microbiol 56:499-504

Gomez DK, Mori K, Okinaka Y, Nakai T, Park SC (2010) Trash fish can be a source of betanodaviruses for cultured marine fish. Aquaculture 302:158-163

Gomez-Gil B, Roque A, Rotllant G, Peinado L and others (2011) Photobacterium swingsii sp. nov., isolated from marine organisms. Int $\mathrm{J}$ Syst Evol Microbiol 61: 315-319

Gouy M, Guindon S, Gascuel O (2010) SeaView version 4: a multiplatform graphical user interface for sequence alignment and phylogenetic tree building. Mol Biol Evol 27:221-224
Hanlon RT, Forsythe W (1990) Diseases of Mollusca: Cephalopoda. 1.1. Diseases caused by microorganisms. In: Kinne O (ed) Diseases of marine animals, Vol III. Biologische Anstalt Helgoland, Hamburg, p 23-46

> Hanlon RT, Forsythe JW, Cooper KM, Dinuzzo AR, Folse DS, Kelly MT (1984) Fatal penetrating skin ulcers in laboratory-reared octopuses. J Invertebr Pathol 44:67-83

Holt JG, Krieg NR, Sneath PHA, Staley JT, Williams ST (1994) Bergey's manual of determinative bacteriology, 9th edn. Williams \& Wilkins, Baltimore, MD

Licciardo G, Garziano A, Nocera G, Gaglio G, Marino F, De Vico G (2005) Contribution to the knowledge of tissue damage due to Aggregata octopiana (Apicomplexa: Aggregatidae) in Octopus vulgaris in the southern Tyrrhenian Sea. Ittiopatologia 2:193-198

Mladineo I, Bocina I (2007) Extraintestinal gamogony of Aggregata octopiana in the reared common octopus (Octopus vulgaris) (Cephalopoda: Octopodidae). J Invertebr Pathol 96:261-264

Mladineo I, Jozi M (2005) Aggregata infection in the common octopus, Octopus vulgaris (Linnaeus, 1758), Cephalopoda: Octopodidae, reared in a flow-through system. Acta Adriat 46:193-199

NaveenKumar S, Shekar M, Karunasagar I, Karunasagar I (2013) Genetic analysis of RNA1 and RNA2 of Macrobrachium rosenbergii nodavirus ( $\mathrm{MrNV}$ ) isolated from India. Virus Res 173:377- 385

> Panzarin V, Patarnello P, Mori A, Rampazzo E, Cappellozza E, Bovo G, Cattoli G (2010) Development and validation of a real-time TaqMan assay for the detection of betanodavirus in clinical specimens. Arch Virol 155: 1193-1203

> Panzarin V, Fusaro A, Monne I, Cappellozza E and others (2012) Molecular epidemiology and evolutionary dynamics of betanodavirus in southern Europe. Infect Genet Evol 12:63-70

Pierce GJ, Allcock L, Bruno I, Bustamante P and others (eds) (2010) Cephalopod biology and fisheries in Europe. ICES Coop Res Rep 303. ICES, Copenhagen

Romalde JL, Barja JL (2010) Bacteria in molluscs: good and bad guys. In: Méndez-Vilas A (ed) Current research, technology and education topics in applied microbiology and microbial biotechnology. Formatex Research Center, Badajoz, p 136-147

Scimeca JM (2012) Cephalopods. In: Lewbart GA (ed) Invertebrate medicine. Wiley-Blackwell, Ames, IA, p 113-125

Shetty M, Maiti B, Santhosh KS, Venugopal MN, Karunasagar I (2012) Betanodavirus of marine and freshwater fish: distribution, genomic organization, diagnosis and control measures. Indian J Virol 23:114-123

> Tsai MA, Wang PC, Liaw LL, Yoshida T, Chen SC (2012) Comparison of genetic characteristics and pathogenicity of Lactococcus garvieae isolated from aquatic animals in Taiwan. Dis Aquat Org 102:43-51

> Vendrell D, Balcàzar JL, Ruiz-Zarzuela I, de Blas I, Gironés O, Múzquiz JL (2006) Lactococcus garvieae in fish: a review. Comp Immunol Microbiol Infect Dis 29:177-198

Wright ES, Yilmaz LS, Noguera DR (2012) DECIPHER, a search-based approach to chimera identification for16S rRNA sequences. Appl Environ Microbiol 78:717-725
Editorial responsibility: Stephen Feist, Weymouth, UK
Submitted: July 28, 2014; Accepted: April 21, 2015

Proofs received from author(s): July 14, 2015 